検討を行った。対象は平成 14 年度第 1 回 OSCEトライアルに参加したSP18 名とし, 採点した点数を評価者の点数 と比較検討した．SP の評価の平均点は 20 点満点で $9.6 \sim 17.4$ 点之開きがあった. SP と評価者の相関関係は, 医療 面接部門ではやや強い相関が, 説明部門ではやや弱い相関が認められた. SP と評価者の評価傾向は 4 タイプに分類 することができ, それぞれのタイプに応じた SP 教育の必要性が示唆された.さらに今後 SP の養成を行う上で, 到達 度と評価基準を明確にし，評価に客観性をあたせる必要があると考えられた。

\title{
Analysis of the Evaluation by Simulated Patients in OSCE Trial of Kyushu Dental College
}

Tetsuro Konoo, Tomoko Ohsumi, Hideo Kurokawa, Masahiro Arita, Yasuo Shono, Chiaki Kitamura, Kensuke Haga, Shuji Awano, Yuji Shinohara, Kazuo Sonoki, Toshimichi Ichida, Ikuko Nishida, Eiji Sakamoto, Keiko Nakamura, Tatsuro Kojo, Kouichi Satoh, Yutaka Hayashida, Yuji Seta, Takatoshi Murata, Kenichi Yoshino, Masamichi Terashita, Makoto Yokota and Tatsuji Nishihara (OSCE Executive Committee, Kyushu Dental College)

To improve the accuracy of the simulated patients (SP) in OSCE, the evaluation by the 18 SP participating in the 2002 OSCE trial of Kyushu Dental College was analyzed. The number of SP was 18 , with the average score of SP ranging from 9.6 to 17.4 out of 20 . Between the scores by SP and instructors, there was a moderate correlation in Medical Interview part and a weak correlation in the Instruction part. The tendency of the scoring between SP and instructors was classified into 4 groups. These results suggested that the necessity of training according to SP type and the standard for evaluation should be clarified.

\section{$\mathrm{P}-5 . \mathrm{CO}_{2}$ レーザーによる歯周治療時の歯の損傷に関する基礎的研究}

○柿川 宏 ${ }^{1}$ 陳 克恭 ${ }^{2} \cdot$ 槙原 正人 ${ }^{1} \cdot$ 永松 $_{\text {有紀 }}$ ·田島 清司 ${ }^{1} \cdot$ 小園 凱夫 ${ }^{1}$

${ }^{1}$ 九歯大·歯理工, ${ }^{2}$ 九歯大·保存 1

近年, 歯科においても各種レーザーの利用が拡大し, 歯周病に対する $\mathrm{CO}_{2} レ$ レ゙ーの治療効果す臨床的に認められ ている.しかし，歯周治療の際に歯に対して不用意にレーザーが照射された場合の，歯への影響に関しては注意が払 われていない，そこで本研究では，歯に不可避的にレーザーが照射された場合の照射条件の影響を検討することを目 的に，まずアクリルレジンを用いてレーザーの照射条件とレジンの損傷との系統的な関係を測定した，その結果，照 射距離を一定にしてレーザ一出力を $0.6 \mathrm{~W}$ から $10 \mathrm{~W}$ まであげていくと, 生じた溝は有意に深くなった。一方, 照射

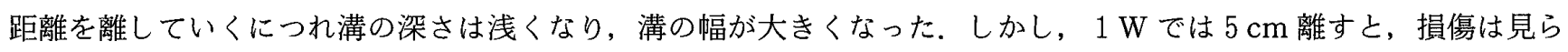
れなくなった。歯においてあ損傷が認められ，HLLT のみならずLLLTで歯周組織に照射する場合にも，可能な限り 歯への照射を避ける必要があることがわかった。

\section{Fundamental Study on the Efficacy of $\mathrm{CO}_{2}$ Laser}

Hiroshi Kakigawa ${ }^{1}$, Ker-Kon $\mathrm{Chen}^{2}$, Masato Makihara ${ }^{1}$, Yuki Nagamatsu${ }^{1}$, Kiyoshi Tajima ${ }^{1}$ and Yoshio Kozono ${ }^{1}{ }^{1}$ Department of Materials Science and ${ }^{2}$ Department of Operative Dentistry, Kyushu Dental College)

The effectiveness of the $\mathrm{CO}_{2}$ laser was well supported through the practitioner's experiences. Although the teeth may be unexpectedly exposed to the laser irradiation during the periodontal treatmento, almost no attention has so far been paid to the effects on the teeth. The present study, therefore, examined the basic effects of the output power, irradiation distance and scanning speed of the $\mathrm{CO}_{2}$ laser on the laser-affected zone of an acrylic resin plate. The depth of the groove significantly increased as the output power increased from 0.6 to $10 \mathrm{~W}$ in $1 \mathrm{~cm}$ distance during one path irradiation. It showed significant decrease with increase in the distance. 